\title{
Impact of Exchange Rate Undervaluation on Manufacturing Sector and Economic Growth in Nigeria
}

\author{
David A. Samuel ${ }^{1 *}$, Enitan Wale-Odunaiya ${ }^{2}$ \\ 1. Department of Economics, Veritas University, Abuja. \\ 2. Department of Economics, Veritas University, Abuja \\ * Email: adesam62@gmail.com
}

\begin{abstract}
This work investigated the consequences of undervaluation of exchange rate in Nigeria on the manufacturing output and economic growth between 1981 and 2019. Vector Error Correction Mechanism was employed and it was found from the impulse response function that real effective exchange rate does not significantly affect economic growth and it is negatively related with manufacturing output. Variance decomposition indicates that the contribution of real exchange rate to manufacturing declined all through. Recommended policies should address the structural bottlenecks in the country to enable supply become more elastic towards demand to enjoy the benefits of lowered prices from devaluation.
\end{abstract}

Key Words: Exchange Rate, Undervaluation, Manufacturing output, Economic Growth

DOI: $10.7176 / \mathrm{JESD} / 12-20-07$

Publication date:October $31^{\text {st }} 2021$

\subsection{Introduction}

The aspiration of every country is to attain sustainable economic growth at every phase of the business cycle and a major factor that can help achieve that is the regulation of exchange rate. The position of exchange rate, whether undervalued or otherwise will to a large extent determine whether some of the activities in the economy will be optimally achieved or not, seeing that it influences both import and export and foreign exchange earnings. Undervaluation of a nation's currency is in relation to two scenarios. Undervaluation can be with relation to the purchasing power parity or could be undervalued in relation to the rate that is needed to attain current account balance. The conceptual understanding of undervaluation of exchange rate relative to purchasing power parity can be viewed in relation two countries relative to each other. For instance, if British Pound is undervalued relative to Canadian dollars, it means that goods and services in UK will be cheaper for Canadians that want to buy UK made goods and Canadian goods are more expensive for UK citizens. Producers of goods in UK will be much better off to export their goods since it is cheaper for foreigners. Increase in domestic productivity will lead to aggregate output and consequently aggregate supply will increase and raise economic growth in the UK.

On the other hand, when a country's currency is undervalued in relation to trade balance or what is referred to as current account trade; it means that the country is undervaluing her currency due to perhaps excess of importation and less importation, leading to deficit of trade. When trade deficit is experienced, the country could devalue or undervalue her currency for the purpose of discouraging imports and increasing export with the purpose of correcting the deficit (Yioyio, 2015). The Washington consensus that was repackaged by Williamson (1990) projected the part that exchange rate plays in the promotion of economic growth in a country. The argument posits that an optimal exchange rate exists that harmonizes both the short and long macroeconomic objectives that makes the domestic goods favourably compete with other foreign goods until equilibrium trade balance is attained.

The assignment of exchange rate in the determination of economic growth was mostly ignored in the early theories of growth, such as Solow-Swan $(1956,1957)$ simply because their analysis was focused on closed economies. The later theories of growth such as Ricardo, and Lewis showed a clearer contribution of exchange rate to the growth process. The growth of the nation, according to them is hinged on the expansion of the manufacturing sector as they engage more of the labour force that increases productivity national output. Exchange rate then becomes the allocative price for factors of production in the manufacturing sector and the tradable goods prices in the sector and the economy 
The effect of exchange rate on economic growth as presented in the literature has been a debate between the traditional and structuralist thoughts. The structuralists opined that overvaluation rather than undervaluation promotes growth, while the traditional view submits that undervaluation promotes growth. The third strand of argument is whether undervaluation promotes growth in developing than developed economies. The fourth line of argument is on the direction of causality between undervaluation and economic growth (Rodrick, 2008). Findings from empirics have shown revealed that overvaluation of currency deters growth while undervaluation stimulates growth (Rodrick, 2008). According to Rodrick (2008), this positive relationship between undervaluation of exchange rate and growth applies only to developing economies. Rodrick (2008) and Karahan (2020) premised the positive relationship between undervaluation of currency and economic growth on the assumption that undervaluation makes domestic goods that are tradable to be cheaper and imports more expensive. That means growth is enhanced through increase in net export due to devaluation.

One of the arguments posits that in trying to promote export, the manufacturing sector is quite pivotal in the process because the sector generates positive externalities into the economy than any other sector. Externalities such as technology spill-overs or technology transfer. Another argument rests on the fact that undervalued exchange rate encourages saving and investment (Dooley, et al., 2004). It was further argued by Rodrick (2008) that manufacturing sectors in these developing countries are not so much affected by distortions and an attempt to remove those distortions is difficult and in order to reallocate resources more towards the manufacturing sector, undervaluation of exchange rate may be the best option. Although these positive externalities that are claimed spill over into the country has not been too obvious (Eichengreen, 2008; Harrison and Rodriguez-Clare, 2008). Apart from the fact that these externalities have not been too obvious, it has not been clearly proved that manufacturing sector is not proportionately affected by distortions in the economy. In this regard, the distortions created by undervaluation have been left unaddressed, and that makes the purported gains from undervaluation doubtful because absorption level has fallen from foreign high price. Almost all the early empirical literatures support the positive relationship between exchange rate undervaluation and economic growth in developing countries (Rodrick, 2008; Schröder, 2013).

The other school of thought is the structuralist whose argument is that exchange rate undervaluation is negatively related to economic growth in the developing countries. Their position is hinged on the fact that most developing economies are dependent on developed economies for importation of raw materials, production inputs, intermediate inputs, for their domestic production (Rodrick, 2008, Ribeiro, McCombie and Lima, 2019). Since undervaluation makes import expensive, then production costs of firms will be affected since the only way to source for these inputs is from the foreign market. High cost of production is therefore a disincentive for production and this will ultimately affect aggregate output and economic growth negatively.

This work intends to find out how exchange rate undervaluation has affected the manufacturing sector output and GDP growth in Nigeria. Most of the works done have mostly examined the effect of exchange rate on economic growth but this work simply intends to find out if the fall in local currency has any negative effect on the manufacturing sector that feeds the national output. In other words, if exchange rate is low, does it translates to crowding out the manufacturing sector in the country and thereby reducing national output?

The following section highlights some of the recent empirical literatures. Section three presents the theoretical framework and section four shows the methodology used for the analysis. Section five presents the results and analysis while section six summarizes and proffers policy recommendations.

\subsection{Empirical Review}

The work of Ribeiro, McCombie, and Lima (2019) on the effect of exchange rate devaluation in 54 developing countries between 1990 and 2010 was carried out from the Structuralist perspective. It was discovered that exchange rate undervaluation showed a negative effect on economic growth. This result is in alignment with the Structuralist position, whose opinion is premised on the fact that distortions and bottlenecks inherent in these economies would impede the transmission of the benefits of devaluation into these economies. The structural bottlenecks in addition to the increased input prices include supply inelasticity of domestic production. Even when the domestic goods and services are relatively cheaper both for local and foreign buyers in addition to the high price of importation, the domestic producers cannot increase production of goods and services due to some unfavourable production conditions and technology. Such conditions that make supply inelastic include rigidities in agricultural production, weak infrastructural facilities, unavailability of sufficient funds to expand output. The implication of this is that, any attempt to undervalue domestic currency will become inflationary due to high cost of imported inputs and excess demand over supply. In summary, the overdependence of domestic firms on foreign 
inputs makes undervaluation of currency not beneficial to domestic economies in the developing countries. When demand for import is inelastic, the country becomes a dumping ground and that makes domestic goods unattractive which again is detrimental to domestic output. The findings of Ribeiro, et al., (2019) were supported by that of Çelik, Çelik and Barak, (2017) on twelve Eastern European and Middle Asian countries between 1995 and 2014. The two studies found that exchange rate devaluation leads to slow economic growth.

Samuel, Udo and Imolemen (2018) studied the link between Naira devaluation and economic growth in Nigeria from 2000 to 2015. Ordinary Least Squares was used in the analysis of the work. It was found from the R square result that over 90 percent of changes in GDP was accounted for by the independent variables including exchange rate, even though its specific contribution was not specified. However, the authors still went ahead to report that devaluation was harmful to the economy simply because the conditions that will make it profitable to Nigeria are not met in the country.

A study on 150 countries by Habib, Mileva and Stracca (2017) focused on finding the effect of exchange rate undervaluation on economic growth in those countries. It was found from the result that exchange rate undervaluation raises real GDP growth in those countries. A similar cross country study was done by Missio, Jayme, Britto, and Oreiro (2015) for 63 developing countries from 1978 to 2007. The finding revealed that there existed a positive relationship between exchange rate and growth of output in the countries. This shows that devaluation exerts a positive impact on growth especially through demand for import elasticity. Obansa, Okoroafor, Aluko, and Eze (2013) interrogated the effect of exchange rate on economic growth in Nigeria from 19702010 and findings showed that the effect is in agreement with earlier studies with a strong positive effect of exchange rate on economic growth. This result again points to the fact that exchange rate devaluation is strongly related to economic growth. In addition to the previously reviewed works that showed positive relationship between exchange rate undervaluation and economic growth, other works like Di Nino, Eichengreen, and Sbracia, (2011), Aman, Ullah, Khan and Khan (2013), Chen (2012), Rodrick, (2008) similarly revealed that exchange rate undervaluation had positive relationship with economic growth in developing countries. On a more specific level, it was revealed that when exchange rate increased by 10 percent output rose by 3.3 percent from the work done by Narayan and Narayan (2007) on Fiji economy

Ayen (2014) investigated how exchange rate devaluation affect Ethiopian economy both in the short and long run with data between 1998 and 2010. A quarterly data with Vector Autoregressive method was employed and the result showed that exchange rate devaluation exerted a negative effect output growth although without any specific effect in the short run. The implication for the country is negative because the output of Ethiopia is not demand elastic since it is more of agricultural products and so policy designs that would help the economy militate against the negative effect of exchange rate needs to be put in place.

Upadhyaya, Rainish, Kaushik and Bhandari (2013) investigated how currency devaluation affected output level in some countries in South-Eastern Asia between 1980 and 2010. After confirming that the time series data satisfied the assumption of required, the panel Error Correction Mechanism methodology was employed and the findings revealed that currency devaluation has a negative relationship with aggregate output both in the short and medium term in these countries.

\subsection{Theoretical Framework}

This work is anchored on the Marshall-Lerner condition which is also referred to as elasticity approach to Balance of Payment. This theory was put forward by Alfred Marshall and Abba P. Lerner. The proposition states that when a country initially begins depreciating their currency, it will initially worsen their Balance of Payment position but as the devaluation continues, it will become improve the BOP on the condition that the sum of the elasticity of export and import in absolute terms is greater than one. If the sum is less than one, devaluation will worsen he BOP, but if it is equal to one, depreciation has no effect on BOP. One of the key assumptions that will make this condition beneficial for the devaluing country includes perfect elasticity of supply from the domestic economy.

\subsection{Model Specification}

This work adapts the work of Rodrick (2008) in his panel estimation of the effect of undervaluation of exchange rate on economic growth, where he used real Gross Domestic Product per capita, undervaluation of exchange rate and other dummy variables as explanatory variables on economic growth. This work will introduce the manufacturing output along with real exchange rate as independent variables. The rationale is to see the effect of 
real exchange rate undervaluation on both economic growth and the tradable sector represented by the manufacturing sector. The functional form of the relationship can therefore be expressed as:

$R G D P g=f($ reer, manout, imp, $\exp )$

And the econometric model of equation (1) can be expressed as:

$R G D P g_{t}=\beta_{1}+\beta_{2}$ reer $_{t}+\beta_{3}$ manout $_{t}+\beta_{4}$ imp $_{t}+\beta_{5} \exp _{t}+\mu_{t} \ldots$

Where $R G D P g_{t}=$ Real Gross Domestic Product growth in time $\mathrm{t}$, reer $_{t}=$ real effective exchange rate at time $\mathrm{t}$, manout $_{t}=$ manufacturing output in time $\mathrm{t}, i m p_{t}=$ import in time t, $\exp _{t}=$ export in time $\mathrm{t}, \beta_{i}=$ are the parameters to be estimated, where $\mathrm{i}=1-5, \mu_{t}=$ error term that is assumed to satisfy the assumptions.

\subsection{A priori Expectations}

$\beta_{2}>0$ if real exchange rate is to have a positive effect on growth

$\beta_{3}>0, \beta_{4}<0, \beta_{5}>0$

After the Unit root test on all the variables using augmented Dickey-Fuller approach (Dickey and Fuller, 1979), it was found that all the variables were not stationary at level, but became stationary after first differenced. It was also confirmed that the variables were cointegrated using Johansen's cointegrating technique (Johansen, 1988). The estimation technique that is suitable for this work shall therefore be Vector Error Correction model (VECM), which is specified below:

\subsection{Vector Error Correction Model}

The Vector Error Correction Model restricts the long run behaviour of the endogenous to converge to their cointegrating relationships while allowing for a short run adjustment. The cointegrating term is known as the error correction term since the deviation from the long run equilibrium is corrected gradually through a series of partial short run adjustments.

Given a three-variable case, $(\mathrm{y}, \mathrm{x}$ and $\mathrm{z})$, the VECM can be specified as:

$$
\begin{aligned}
& \Delta y_{t}=\alpha+\sum_{i=1}^{k-1} \beta_{i} \Delta y_{t-i}+\sum_{j=1}^{k-1} \delta_{j} \Delta x_{t-j}+\sum_{m=1}^{k-1} \theta_{m} \Delta z_{t-m}+\rho_{1} E C T_{t-1}+e_{1 t} \\
& \Delta x_{t}=\tau+\sum_{i=1}^{k-1} \beta_{i} \Delta y_{t-i}+\sum_{j=1}^{k-1} \delta_{j} \Delta x_{t-j}+\sum_{m=1}^{k-1} \theta_{m} \Delta z_{t-m}+\rho_{2} E C T_{t-1}+e_{2 t} \\
& \Delta z_{t}=\gamma+\sum_{i=1}^{k-1} \beta_{i} \Delta y_{t-i}+\sum_{j=1}^{k-1} \delta_{j} \Delta x_{t-j}+\sum_{m=1}^{k-1} \theta_{m} \Delta z_{t-m}+\rho_{3} E C T_{t-1}+e_{3 t}
\end{aligned}
$$

Where: $\mathrm{k}-1=$ the lag length and it is reduced by 1 because of the differencing. $\beta_{i}, \delta_{j}, \theta_{m}=$ short run dynamic coefficients of the model's adjustment long run equilibrium.

$\rho_{1}=$ speed of adjustment parameter with a negative sign

$E C T_{t-1}=$ the error correction term, which is the lagged values of the residuals obtained from cointegrating regression of the dependent variable on the regressors. It contains long run information derived from the long run cointegrating relationships.

$u_{i t}=$ residuals or error terms referred to as impulses, shocks or innovations.

We can re-present the models above in a more compact format, where the dependent variable is expressed as a function of its lag and the lag of other variables in the system.

$\Delta Y_{t}=\alpha+\sum_{i=1}^{k-1} \gamma_{i} \Delta Y_{t-i}+\sum_{j=1}^{k-1} \emptyset_{j} \Delta X_{t-j}+\sum_{m=1}^{k-1} \theta_{m} \Delta Z_{t-m}+\rho_{1} E C T_{t-1}+u_{t}$

Therefore,

$$
E C T_{t-1}=\left[\gamma_{i} Y_{t-1}-\emptyset_{j} X_{t-1}-\theta_{m} Z_{t-1}\right]
$$


$=$ the lagged OLS residual obtained from the long run cointegrating equation:

$Y_{t}=\left[Y_{t-1}-\emptyset_{1} X_{t-1}-\theta_{1} Z_{t-1}\right]$

The ECT explains that previous period's deviation from long run equilibrium influences the short run movement in the dependent variable. $\rho_{1}=$ the coefficient of the ECT and represents the speed of adjustment. It measures the speed at which $\mathrm{Y}$ returns to equilibrium after changes in $\mathrm{X}$ and $\mathrm{Z}$ have occurred.

In this work, we have four variables, and they are presented as follows,

Where the Vector $\boldsymbol{X}_{\boldsymbol{t}}$ is defined as follows:

$X_{t}=f\left(R E E R_{t} M\right.$ NNOUT $\left._{t}, I M P_{t}, E X P_{t}\right)$

The VECM model for this work is specified as follows:

$$
\begin{gathered}
\Delta R G D P g_{t}=\alpha+\sum_{i=1}^{k-1} \beta_{i} \Delta R E E R_{t-i}+\sum_{j=1}^{k-1} \delta_{j} \Delta M A N O U T_{t-j}+\sum_{m=1}^{k-1} \theta_{m} \Delta I M P_{t-m}+\sum_{n=1}^{k-1} \vartheta_{n} \Delta E X P_{t-n}+ \\
\rho_{1} E C T_{t-1}+u_{1 t}
\end{gathered}
$$

\subsection{Nature and Sources of Data}

The data for this work is an annual time series secondary data. The data include Real Gross Domestic Product growth, (RGDPg), sourced from the National Bureau of Statistics (NBS), Real exchange rate proxied by real effective exchange rate from the World Bank Development Indicator, Manufacturing output from NBS, Import and Export from Central Bank of Nigeria Statistical Bulletin. The data spans the period of 38 years from 1981 to 2019.

\subsection{Presentation and analysis of Results}

\subsection{Unit Root Test}

Table 4.1 shows the results of the Unit root test for the variables. It showed that all the variables have unit root at level (with the probability values higher than 5 percent level of significance), but when differenced once, they became stationary. This is indicated by the Probability values of all the variables less than 5 percent after first differenced. This implies that all of them are integrated of order one. This is the condition that enables us to go for cointegration using Johanson's cointegration technique.

Table 4.1: Unit Root Test using Augmented Dickey-Fuller

\begin{tabular}{|l|l|l|l|l|l|l|l|}
\hline & \multicolumn{2}{|l}{ At Level } & \multicolumn{2}{l|}{ At First Difference } \\
\hline Variable & ADF stat & $\mathbf{5 \%}$ level & Prob. Value & ADF stat & $\mathbf{5 \%}$ level & $\begin{array}{l}\text { Prob. } \\
\text { Value }\end{array}$ & $\begin{array}{l}\text { Order of } \\
\text { Integration }\end{array}$ \\
\hline & & & & & & & \\
RGDPg & -2.75857 & -2.94115 & 0.0739 & -11.634 & -2.94115 & 0.0000 & $\mathrm{I}(1)$ \\
\hline REER & -1.91992 & -2.93899 & 0.3201 & -4.29871 & -2.94115 & 0.0016 & $\mathrm{I}(1)$ \\
\hline MANOUT & -1.42598 & -2.93899 & 0.5597 & -6.5951 & -2.94115 & 0.0000 & $\mathrm{I}(1)$ \\
\hline IMP & 0.275307 & -2.93899 & 0.9739 & -5.79862 & -2.94115 & 0.0000 & $\mathrm{I}(1)$ \\
\hline EXPO & -0.76823 & -2.93899 & 0.8169 & -4.59015 & -2.94115 & 0.0007 & $\mathrm{I}(1)$ \\
\hline
\end{tabular}

Source: Author generated using Eviews 10 


\subsection{Cointegration Test Results}

Cointegration shows the long relationship among the variables under study. Table 4.2 shows the tests using both Trace and Max-eigen tests. The Trace tests indicated 5 cointegrating models while the Max-eigen test shows 2 . As a result of this cointegration and the unit root test results, we therefore employ the Vector Error Correction Mechanism as the estimation method for the work.

Table 4.2: Cointegration Test using Johansen Method

\begin{tabular}{|c|c|c|c|c|c|c|}
\hline \multirow[b]{2}{*}{$\begin{array}{l}\text { Null } \\
\text { Hypothesis }\end{array}$} & \multicolumn{3}{|l|}{ Trace Test } & \multicolumn{3}{|c|}{ Max-eigen Test } \\
\hline & Trace Stat & $5 \%$ Level & $\begin{array}{l}\text { Prob. } \\
\text { Value }\end{array}$ & $\begin{array}{l}\text { Max-eigen } \\
\text { Stat }\end{array}$ & $5 \%$ Level & $\begin{array}{l}\text { Prob. } \\
\text { Value }\end{array}$ \\
\hline None & 105.1967 & 69.81889 & 0.0000 & 41.09227 & 33.87687 & 0.0058 \\
\hline At most 1 & 64.10438 & 47.85613 & 0.0008 & 31.25818 & 27.58434 & 0.0161 \\
\hline At most 2 & 32.84620 & 29.79707 & 0.0216 & 15.46521 & 21.13162 & 0.2576 \\
\hline At most 3 & 17.38100 & 15.49471 & 0.0257 & 13.17179 & 14.26460 & 0.0739 \\
\hline At most 4 & 4.209201 & 3.841466 & 0.0402 & 4.209201 & 3.841466 & 0.0402 \\
\hline
\end{tabular}

Source: Author generated using Eviews 10

\subsection{Vector Error Correction Mechanism}

The model in equation (9) was estimated and the error correction term coefficient is -0.503681 and the t-statistic is -2.15990 . This shows that the ECT satisfies the sign expectation (negative) and it is statistically significant. That also implies that the adjustment in the long run to short run disequilibrium will be adjusted at the speed of 50 percent per annum.

\subsubsection{Impulse Response Function}

Impulse response function explains the reaction of an endogenous variable to one of the innovations on the other variables in the model. In other words, it describes the evolution of the variable of interest along a specified time horizon after a shock is given in a moment.

The Impulse Response function was also estimated and shown in the figure 4.1 below;

The response of RGDP growth to real effective exchange rate is very insignificant as can be seen from figure 4.1, howbeit, it is in the positive region. The response of RGDP growth to manufacturing output is in the negative region all through the period under study. Manufacturing output responded negatively to import all through the period. RGDP growth responded to export positively and quite significant but only rose from period 1 to 2 and thereafter the momentum died out. Manufacturing output responded to real effective exchange rate negatively all through the period. So it is clear from the impulse response function that real effective exchange rate has a negative effect on manufacturing output and manufacturing output similarly exerts a negative effect on real GDP growth. 


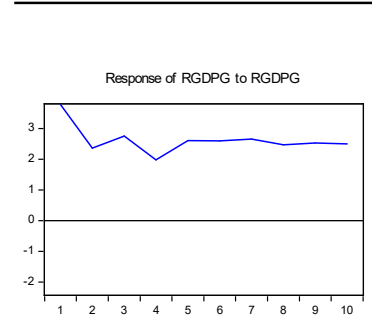

Response of RGDPG to EXPO

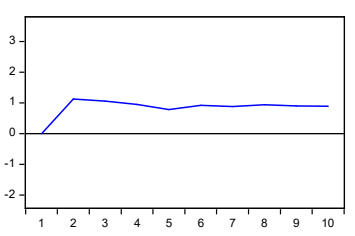

Response of MANOUT to IMP

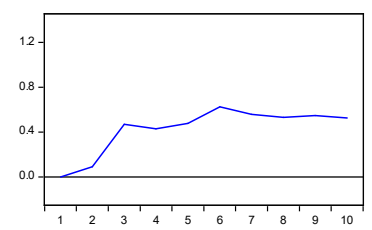

Response to Cholesky One S.D. (d.f. adjusted) Innovations

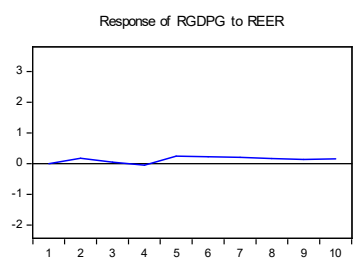

Response of MANOUT to RGDPG

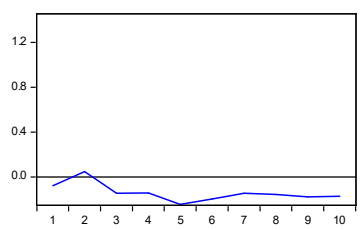

Response of MANOUT to EXPO

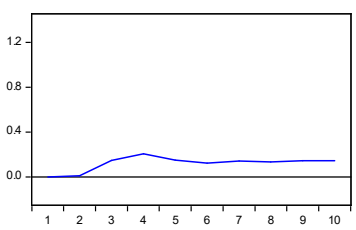

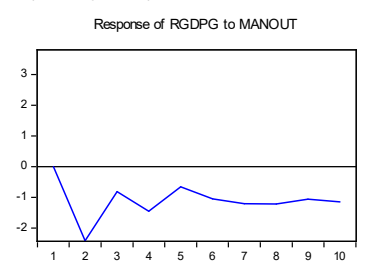

Response of MANOUT to REER

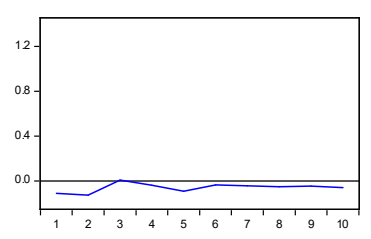

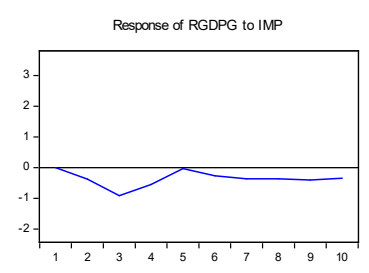

Response of MANOUT to MANOUT

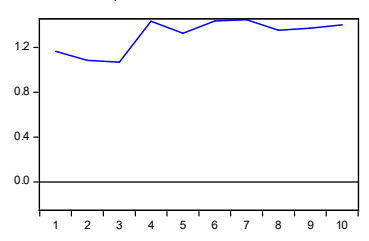

\section{Figure 4.1: Impulse Response Function}

Source: Author generated using Eviews 10

This direction of relationship confirms the position of the Structuralist that exchange rate undervaluation has a contractionary effect on growth.

\subsubsection{Variance Decomposition}

While impulse response functions trace the effects of a shock to one endogenous variable on to the other variables in the VAR system, variance decomposition separates the variation in an endogenous variable into the component shocks to the VAR. Thus, the variance decomposition provides information about the relative importance of each random innovation in affecting the variables in the VAR.

The variations in RGDP growth was explained majorly by the variations in itself. The proportion of the variations in RGDP growth that is explained by REER is not more than 1 percent all through the period under study. That supports the explanation provided by the impulse response function. Similarly the variations in RGDP growth that is explained by manufacturing output is less than 22 percent and it declined all through the period under study. Variations in export could not explain variations in RGDP growth more than 8.3 percent. Similarly, real effective exchange rate could not account for variations in manufacturing output more than 1 percent all through the period. 
Journal of Economics and Sustainable Development

ISSN 2222-1700 (Paper) ISSN 2222-2855 (Online)

Vol.12, No.20, 2021

Table 4.3: Variance Decomposition

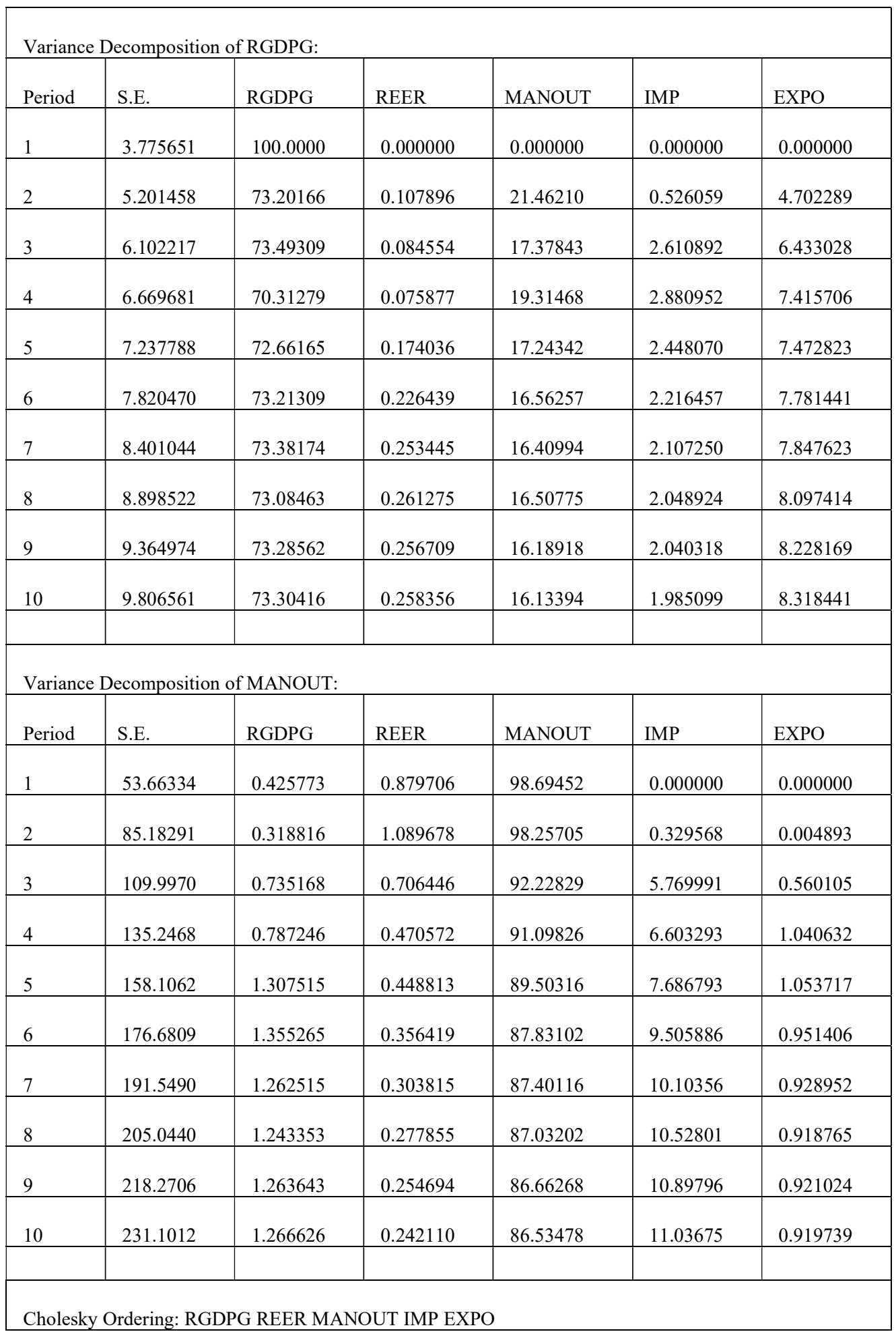

Source: Author generated using Eviews 10

This goes on to tell us that the impact of real exchange rate on manufacturing output is very insignificant and therefore consequently has very little impact on growth. 


\subsubsection{Granger causality test}

This test shows whether an independent variable at the lag lengths allowed can cause the dependent variable.

Table 4.4: Granger causality test

\begin{tabular}{|c|c|c|c|c|c|c|c|}
\hline \multicolumn{4}{|c|}{ 4.4a: Dependent variable: D(RGDPG) } & \multicolumn{4}{|c|}{ 4.4b: Dependent variable: D(MANOUT) } \\
\hline Excluded & Chi-sq & $\mathrm{df}$ & Prob. & Excluded & Chi-sq & $\mathrm{df}$ & Prob. \\
\hline D(REER) & 1.016741 & 2 & 0.6015 & $\mathrm{D}(\mathrm{RGDPG})$ & 3.718319 & 2 & 0.1558 \\
\hline D(MANOUT) & 11.13846 & 2 & 0.0038 & D(REER) & 0.769562 & 2 & 0.6806 \\
\hline $\mathrm{D}(\mathrm{IMP})$ & 1.201809 & 2 & 0.5483 & $\mathrm{D}(\mathrm{IMP})$ & 3.152399 & 2 & 0.2068 \\
\hline $\mathrm{D}(\mathrm{EXPO})$ & 0.499133 & 2 & 0.7791 & $\mathrm{D}(\mathrm{EXPO})$ & 0.163104 & 2 & 0.9217 \\
\hline All & 14.748 & 8 & 0.0642 & All & 9.373031 & 8 & 0.3118 \\
\hline
\end{tabular}

Source: Author generated using Eviews 10

Table 4.4a shows that only manufacturing output can granger cause growth with a p-value (0.0038) less than 5 percent, and from table $4.4 \mathrm{~b}$, none of the independent variables could granger cause manufacturing output.

\subsection{Conclusion and Policy recommendation}

This work has examined the impact of exchange rate undervaluation on manufacturing output economic growth in Nigeria. Following the available data and the analysis of the result, it has been made clear that exchange rate undervaluation has a negative effect on manufacturing output, which is the tradable sector that should have transmitted the undervaluation into the economy. Consequently, manufacturing output has a negative effect on growth. It was also established that exchange rate undervaluation cannot cause growth. That means there is no causality running from exchange rate to both manufacturing output and economic growth.

It is therefore recommended that if the undervaluation will be beneficial to the country's output growth, there is a need to address the structural bottlenecks that will not allow supply to match both the domestic and foreign demand. There is also the need to engage a national re-orientation on the need for citizens to patronize locally made goods to boost the domestic aggregate demand and incentivize productivity.

\section{References}

Aman, Q., Ullah, I., Khan, M.I. and Khan, S. (2013). Linkages between Exchange Rate and Economic Growth in Pakistan, European Journal of Law and Economics. $\quad 44(1), 157-164$.

Ayen, Y. W. (2014). The effect of currency devaluation on Output: The case of Ethiopian economy. Journal of Economics and International Finance, 6(5), 103-111.

Çelik, T., Çelik B. and Barak, D. (2017). Real Exchange Rate and Economic Growth Relationship in Transition Economies. Suleyman Demirel University, The Journal Sciences, 22(3), 877-890. of Faculty of Economics and Administrative

Chen, J. (2012). Real Exchange Rate and Economic Growth: Evidence from Chinese Provincial data. PSE Working Papers, 2012-05, 127. 
Dickey, D. A. and Fuller, W. A. (1979). Distribution of the estimators for autoregressive time series with a unit root. Journal of the American Statistical Association. 74 (366a): 427-431

Di Nino, V., Eichengreen, B. and Sbracia, M. (2011). Real Exchange Rates, Trade, and Growth: Italy 18612011. Banca d'Italia Economic History Working Papers, No. 10.

Dooley, M. P., D. Folkerts-Landau, and P. Garber (2004). The revived Bretton Woods system.. International Journal of Finance and Economics, 9(4), 307-313.

Eichengreen, B. (2008). The real exchange rate and economic growth. Commission on Growth and Development, Working Paper No. 4.

Habib M. M., Mileva, E. and Stracca, L. (2017). The Real Exchange Rate and Economic Growth: Revisiting the case using External Instruments. Journal of International $\quad$ Money and Finance, 73, 386-398.

Harrison, A. E. and A. Rodríguez-Clare (2009). Trade, foreign investment, and industrial policy. MPRA Paper 15561, University Library of Munich, Germany.

Johansen, S., (1988). Statistical Analysis of Cointegration Vectors. Journal of Economic Dynamics and Control, $2-3(12), 231-254$.

Missio, F. J., Jayme, G. F., Britto, G. and Oreiro, J. L. (2015). Real Exchange Rate and Economic Growth: New Empirical Evidence. Metroeconomica, 66(4), 686-714.

Narayan, P.K. and Narayan, S. (2007). Is Devaluation Expansionary or Contractionary? Empirical Evidence from Fiji. Applied Economics, 39, 2589-2598.

Rodrik, D. (2008). The real exchange rate and economic growth. Brookings Papers on Economic Activity $2008,365-412$.

Karahan, O. (2020). Influence of Exchange Rate on the Economic Growth in the Turkish Economy. 5817/FAI2020-1-2, No. $1 / 2020$

Obansa, S. A. J., Okoroafor, O. K. D., Aluko, O. O. and Millicent Eze (2013). Percieved Relationship between Exchange Rate, Interest Rate and Economic Growth in Nigeria: 1970-2010. American Journal of Humanities and Social Sciences, 1(3), 116-124.

Ribeiro, R. S. M., McCombie, J. S. L. and Lima, G. T. (2019). Does Real Exchange Rate Undervaluation Really Promote Economic Growth? Structural Change and Economic Dynamics, 50, 408-417.

Samuel, U. E., Udo, B. E. and Imolemen, K. I. (2018). The Implication of Naira Devaluation to the Nigeria's Economic Development. Business and Economics Journal. 9(1), 1-6.

Schröder, M. (2013). Should Developing Countries Undervalue Their Currencies? Australian National University Working Paper, 2013/12.

Solow, R. M. (1957). Technical change and the aggregate production function. Review of Economics and Statistics. The MIT Press. 39 (3): 312-320.

Swan, T. W. (1956). "Economic growth and capital accumulation". Economic Record. Wiley. 32 (2): 334 361.

Upadhyaya, K.P, Rainish, R., Kaushik, N. and Bhandari, R. N. (2013). Exchange Rate Adjustment And Output In South-East Asia. The Journal of Applied Business Research, 29(4), 1223-1230.

Williamson, J. (1990). What Washington means by policy reform. In J. Williamson (Ed.), Latin American Adjustment: HowMuch Has Happened?, 5-20. Peterson Institute for International Economics. 
Yioyio, C. G. (2015). What caused the Asian currency and financial crisis? Part I: A macroeconomic overview. NBER Working Paper 6833. 